\title{
ACTH treatment disrupts ovarian IGF-I and steroid hormone production
}

\author{
M M Viveiros and R M Liptrap
}

Department of Biomedical Sciences, Ontario Veterinary College, University of Guelph, Guelph, Ontario, Canada N1G-2W1

(Requests for offprints should be addressed to M M Viveiros, The Jackson Laboratory, 600 Main St, Bar Harbor, Maine 14609, USA; E-mail: mmv@jax.org)

\begin{abstract}
Hyper-adrenal activity and increased glucocorticoid hormone release are associated with disruptions in reproductive function and adverse effects on the ovary. The aim of this investigation was to determine whether elevated glucocorticoid hormone levels can influence ovarian IGF-I synthesis and action in vivo. To elevate endogenous glucocorticoid levels, gilts were treated with ACTH during the luteal phase of the oestrous cycle (days 9-13) while the control group received saline. The gilts were subsequently ovariectomized on either day 14 or day 18 of the oestrous cycle. Follicular fluid (FF) was collected from individual follicles; IGF-I and steroid hormone concentrations were determined by radioimmunoassay, and IGF-binding protein (IGFBP) expression was assessed by Western ligand blotting. Granulosa cells were also recovered and placed in culture to determine IGF-I, progesterone $\left(\mathrm{P}_{4}\right)$ and oestradiol-17 $\beta\left(\mathrm{E}_{2}\right)$ production levels. The cells were cultured in serum-free medium for 5 days and
\end{abstract}

supplemented with: (a) media alone, (b) IGF-I, (c) FSH and androstenedione $\left(\mathrm{A}_{4}\right)$, or (d) IGF-I with FSH and $\mathrm{A}_{4}$. The FF from ACTH-treated gilts was characterized by elevated $(P<0 \cdot 05)$ cortisol levels on day 14 and lower $(P<0.05) \mathrm{E}_{2}$ values on both day 14 and day 18. Lower $(P<0 \cdot 05)$ IGF-I concentrations were also measured in the FF of ACTH-treated gilts collected on day 18. This altered hormone profile in FF was associated with impaired IGF-I and steroid hormone synthesis by granulosa cells. IGFstimulated $\mathrm{P}_{4}$ production $(P<0 \cdot 01)$ by cells recovered from ACTH-treated gilts on day 14 was lower $(P<0 \cdot 05)$. By day $18, \mathrm{IGF}-\mathrm{I}, \mathrm{P}_{4}$ and $\mathrm{E}_{2}$ production by cells from the ACTH group were all significantly $(P<0 \cdot 05)$ lower. These results demonstrate that increased glucocorticoid concentrations can disrupt subsequent ovarian IGF-I synthesis and IGF action in vivo and can, potentially, impair follicle maturation.

Journal of Endocrinology (2000) 164, 255-264

\section{Introduction}

Hyper-adrenal activity and stress-associated stimulation of the hypothalamic-pituitary-adrenal axis have been reported to disrupt reproductive function (Moberg 1987). While the mechanism of action is not well understood, previous research suggests that increased adrenal glucocorticoid hormone release may mediate the adverse effects on the reproductive process. In the pig, poor follicle development, reduced ovulation rates and ovarian cyst formation have been reported in association with elevated glucocorticoid concentrations (Liptrap 1970, 1993). Exposure to high glucocorticoid levels during the late follicular phase of the oestrous cycle can disrupt gonadotrophin release (Barb et al. 1982, Li \& Wagner 1983, Fonda et al. 1984). However, administration of glucocorticoids or adrenocorticotrophic hormone (ACTH) to sows during the luteal phase does not significantly alter the pulsatile secretion of luteinizing hormone ( $\mathrm{LH})$ and follicle-stimulating hormone (FSH), yet lowers both plasma and follicular fluid (FF) oestrogen levels (Frautschy
\& Liptrap 1988). In addition, an increased percentage of follicles fail to reach ovulatory size (Frautschy \& Liptrap 1988) and exhibit morphological signs of degeneration (Gee et al. 1991), thus indicating a possible direct glucocorticoid influence on ovarian function.

The expression of glucocorticoid receptors in rat ovarian cells (Schreiber et al. 1982) and the detection of cortisol binding globulin in FF (Mahajan et al. 1980) supports the possibility of direct glucocorticoid action in the ovary. Glucocorticoid hormone metabolism by ovarian cells is also indicated by the expression of $11 \beta$-hydroxysteroid dehydrogenase mRNA (Tetsuka et al. 1997) and enzyme activity in human granulosa cells (Michael \& Cooke 1994). Furthermore, data from in vitro studies demonstrate cortisol-mediated disruptions in steroid hormone synthesis. Exposure to high glucocorticoid concentrations during culture lowers FSH-stimulated oestradiol-17 $\beta\left(\mathrm{E}_{2}\right)$ synthesis, but promotes progesterone $\left(\mathrm{P}_{4}\right)$ production by murine (Hsueh \& Erickson 1978, Adashi et al. 1981, Schoonmaker \& Erickson 1983), porcine (Danisova et al. 1987), and bovine granulosa cells (Kawate et al. 1993). 
Recent work also demonstrated that porcine granulosa cells cultured with high levels of cortisol respond with lower insulin-like growth factor (IGF)-I synthesis and reduced IGF-I-stimulated $\mathrm{P}_{4}$ production (Viveiros \& Liptrap 1999).

Significant research over the last decade supports the existence of an 'intra-ovarian insulin-like growth factor system' in women, rodents and a number of domestic species including the pig (Adashi et al. 1985a, Guidice 1992, Hammond et al. 1993). Both IGF-I and IGF-II, as well as IGF receptors and various IGF-binding proteins (IGFBPs) are expressed in the porcine ovary (Hammond et al. 1993, Spicer \& Echternkamp 1995). IGF-I is secreted by granulosa cells in culture, and IGF-I mRNA expression has been detected in both granulosa and luteal cells (Gadsby et al. 1996, Yuan et al. 1996). Several IGFBPs have also been isolated from FF (Mondschein et al. 1991, Howard \& Ford 1992) and are specific products of the ovary, with mRNA expression confirmed in granulosa and luteal cells (Samaras et al. 1993, Gadsby et al. 1996, Yuan et al. 1996). Functionally, IGF-I can regulate ovarian steroidogenesis and is thought to play an important role in follicle development (Guidice 1992, Hammond et al. 1993).

If high glucocorticoid hormone levels disrupt ovarian IGF-I production and/or IGF-I action in vivo, as demonstrated with granulosa cell culture (Viveiros \& Liptrap 1999), follicle development may be adversely affected. To assess this possibility, endogenous glucocorticoid concentrations were elevated by ACTH administration to gilts during the luteal phase of the oestrous cycle (days 9-13). The treatment regime used significantly elevates both plasma and FF cortisol levels (Montgomery et al. 1997) without disrupting gonadotrophin secretion (Frautschy \& Liptrap 1988). The ovaries were subsequently recovered on day 14 and day 18 to assess granulosa cell IGF-I and steroid hormone production, as well as FF hormone levels.

\section{Materials and Methods}

\section{Animals and experimental procedure}

In this investigation, sexually mature Yorkshire-Landrace gilts, which ranged in age from 5 to 6.5 months and had an approximate bodyweight of $125 \mathrm{~kg}$, were used. All animals were maintained according to the Guidelines of the Canadian Council on Animal Care; they were housed in individual pens, subjected to controlled light conditions (14 h light, $10 \mathrm{~h}$ darkness) and fed a commercial sow ration (16\% protein) with water freely available. Timing of the oestrous cycle for each gilt was determined by daily observation, with day 0 of the cycle denoting the first day of characteristic oestrous behaviour including a positive response to back pressure and to mounting by a boar. Two successive cycles were observed for each animal prior to random allocation to either the control or the treatment group. Treated gilts received intra-muscular injections $(0.5 \mathrm{IU} / \mathrm{kg}$ bodyweight $)$ of a long acting preparation of ACTH (ACTHAR GEL, Rorer Canada Inc., Bramalea, ON, Canada) at 12-h intervals for 5 days (from day 9 to day 13), while control gilts received an equivalent volume of physiological saline under the same conditions. This treatment effectively raises both plasma and follicular fluid cortisol concentrations to mean values of 80 and $30 \mathrm{ng} / \mathrm{ml}$ respectively (Montgomery et al. 1997).

\section{Follicular fluid and granulosa cell collection}

The gilts were ovariectomized by mid-ventral laparotomy on day 14, approximately $12 \mathrm{~h}$ after the final ACTH injection (control $n=5$, ACTH-treated $n=5$ ), or on day 18,5 days after treatment was discontinued (control $n=5$, ACTH-treated $n=5$ ). Upon recovery, the ovaries were rinsed with phosphate buffered saline (PBS) and the 7 largest follicles (with a minimum diameter of $3 \mathrm{~mm}$ ) per ovary were dissected from the interstitial tissue. Follicular fluid was collected by aspiration from individual follicles and stored at $-20^{\circ} \mathrm{C}$ for subsequent assessment of IGF-I, IGFBP and steroid hormone concentrations. To recover granulosa cells for culture, the follicles were bisected, flushed with PBS and gently scraped with a rubber-tipped spatula. Cells collected from both ovaries were pooled, washed twice and dispersed in $5 \mathrm{ml}$ Dulbecco's Modified Eagle's Medium Nutrient Mixture/Ham F-12 (DMEM/ F-12) (Gibco BRL, Burlington, ON, Canada). The cells were counted on a haemocytometer and cell viability was determined using a trypan blue dye exclusion test.

\section{Cell culture}

Granulosa cells were cultured in $24-w e l l$ plates, at a density of $0.5 \times 10^{6}$ viable cells per well, in $1 \mathrm{ml}$ DMEM/ F-12 supplemented with $0.1 \mathrm{mM}$ non-essential amino acids (Gibco BRL), and an antibiotic-antimycotic solution (Gibco BRL) containing penicillin (100 U), streptomycin $(10 \mu \mathrm{g} / \mathrm{ml})$ and amphotericin B $(0.025 \mu \mathrm{g} / \mathrm{ml})$. At the onset of culture the cells were treated with different hormone supplements (3 replicates for each treatment) which included: (1) medium alone to assess basal production, (2) $10 \mathrm{ng} / \mathrm{ml}$ IGF-I (Boehringer Mannheim, Laval, PQ, Canada), (3) $10 \mathrm{ng} / \mathrm{ml}$ porcine $\mathrm{FSH}(100 \times$ the NIH-FSH-P1 standard, Cedarlane Laboratories, Hornby, ON, Canada $+100 \mathrm{ng} / \mathrm{ml}$ androstenedione $\left(\mathrm{A}_{4}\right)$ as an aromatase substrate, or (4) $10 \mathrm{ng} / \mathrm{ml}$ IGF-I with FSH $(10 \mathrm{ng} / \mathrm{ml})$ and $\mathrm{A}_{4}(100 \mathrm{ng} / \mathrm{ml})$. Culture was carried out under standard conditions of $95 \%$ air and $5 \% \mathrm{CO}_{2}$ at $37{ }^{\circ} \mathrm{C}$ for 5 days. A sample $(150 \mu \mathrm{l})$ of medium was collected after $12 \mathrm{~h}$ and $24 \mathrm{~h}$ of culture and then subsequently at $24-\mathrm{h}$ intervals, with a media change at $48 \mathrm{~h}$. The samples were stored at $-20{ }^{\circ} \mathrm{C}$ for future radioimmunoassay (RIA) analysis to determine $\mathrm{E}_{2}, \mathrm{P}_{4}$ and IGF-I levels. Hormone 
levels are expressed as 'cumulative hormone concentrations' to indicate that concentrations reported at $72 \mathrm{~h}$ and beyond have the $48 \mathrm{~h}$ value added. The experiment was replicated 5 times for control and ACTH-treated gilts, with ovaries recovered on both day 14 and day 18 .

\section{Insulin-like growth factor-I measurement}

Insulin-like growth factor concentrations in the FF and culture media were determined using a specific radioimmunoassay (Houseknecht et al. 1988). Prior to assay, the IGFBPs were separated from the IGF ligand by acidification of the samples with $0 \cdot 2 \mathrm{M}$ glycylglycine hydrochloride for $24 \mathrm{~h}$ at room temperature. An IGF-I (Boehringer Mannheim) standard curve was prepared by serial dilution, and ranged from $0 \cdot 01-1 \cdot 0 \mathrm{ng}$. The samples and standards were incubated with rabbit anti-human IGF-I (UKB 487; distributed for research by the Hormone Distribution Program of NIDDK, National Institutes of Health, Baltimore, MD, USA) for $1 \mathrm{~h}$ at room temperature. Subsequently, ${ }^{125}$ I-labelled IGF-I ( 10000 c.p.m. $/ 100 \mu$ l, Amersham Canada Ltd, Oakville, ON, Canada) was added and the samples were maintained for $48 \mathrm{~h}$ at $4{ }^{\circ} \mathrm{C}$. Goat anti-rabbit serum (Daymar Laboratories, Toronto, ON, Canada) was used to separate the bound and free fractions. The inter- and intra-assay coefficients of variation were $13.9 \%$ and $8.6 \%$ respectively. The anti-IGF-I is reported to cross-react $0.5 \%$ with IGF-II and minimally with insulin at $10^{-6} \mathrm{M}$.

\section{Insulin-like growth factor binding protein expression}

The IGFBP profile in FF from individual follicles was determined by Western ligand blotting procedures (Hossenlopp et al. 1986). Follicular fluid samples were initially separated by electrophoresis using SDS-PAGE under non-reducing conditions for $1.5 \mathrm{~h}$ and then transferred onto a nitrocellulose membrane by electroblotting for $1 \mathrm{~h}$ at 100 volts. The membrane was hybridized overnight with approximately $0 \cdot 25 \mu \mathrm{Ci}{ }^{125}$ I-labelled IGF-I (Amersham). The following day, the membrane was taken through a series of washes with $0.15 \mathrm{M} \mathrm{NaCl}$ supplemented with $0 \cdot 1 \%$ Tween 20 , then air dried and exposed to film (Amersham) for 14 days at $4{ }^{\circ} \mathrm{C}$. The autoradiographs were analysed by the NIH image analysis system. The IGFBP band(s) intensity in FF samples was expressed as a percentage of the corresponding IGFBP expressed in a porcine serum standard which was run in parallel on the same gel (Cataldo \& Guidice 1992).

\section{Steroid hormone measurement}

Specific radioimmunoassays, previously validated in the laboratory (Liptrap \& Cummings 1991), were used to determine cortisol, $\mathrm{P}_{4}, \mathrm{E}_{2}$, and $\mathrm{A}_{4}$ levels in FF, as well as $\mathrm{P}_{4}$ and $\mathrm{E}_{2}$ concentrations in the culture media. Each sample was assayed in duplicate after extraction with diethyl ether (Caledon Laboratories Ltd, Georgetown, ON, Canada). All radioisotopically labelled steroids were purchased from Amersham, and all non-radioactive steroid standards from Steranti Research Ltd (St Albans, Herts, UK). The cortisol antiserum was obtained from Sigma Chemical Co. (St Louis, MO, USA) while the $\mathrm{A}_{4}$ and $\mathrm{P}_{4}$ antisera were purchased from Cedarlane Laboratories. The $\mathrm{E}_{2}$ antiserum was generously provided by Dr J Pratt (Isotopenlaboratorium Academisch, Groningen, The Netherlands). The intra-assay variation was $4.9 \%$ for cortisol, $4 \cdot 6 \%$ for $\mathrm{P}_{4}, 6 \cdot 7 \%$ for $\mathrm{E}_{2}$ and $8.3 \%$ for $\mathrm{A}_{4}$, while the interassay variation was $9 \cdot 8 \%, 10 \cdot 3 \%, 9 \cdot 6 \%$ and $10 \cdot 9 \%$ respectively

\section{Statistical analysis}

All values are reported as a mean \pm standard error (S.E.). Analysis of variance (ANOVA) procedures, by the Statistical Analysis System (1985), were used for the comparison among means. The effect of ACTH treatment and day of the oestrous cycle on follicle size and FF hormone levels was determined. The effect of ACTH treatment and specific hormone supplementation during culture on granulosa cell IGF-I, $\mathrm{E}_{2}$ and $\mathrm{P}_{4}$ production was also determined. Pair-wise comparison between means was determined using the Student-Newman-Keuls test and the experiment-wise level of significance $(a l p h a=0.05)$ was controlled using Bonferroni's adjustment.

\section{Results}

Individual follicles ( $n=70$ per group) were recovered from control and ACTH-treated gilts for evaluation on day 14 and day 18 of the oestrous cycle. On day 14, the mean follicle diameter $(\mathrm{mm} \pm$ s.E.) was similar in the ACTH and the control group $(3 \cdot 8 \pm 0 \cdot 17$ vs $4 \cdot 2 \pm 0 \cdot 22)$. However, on day 18 the mean diameter of follicles from the ACTHtreated group $(5 \cdot 2 \pm 0 \cdot 25)$ was smaller $(P<0 \cdot 05)$ than the control group $(7 \cdot 6 \pm 0 \cdot 35)$.

\section{IGF-I and IGFBP profiles in follicular fluid}

Mean IGF-I levels (ng/ml \pm S.E.) measured in control follicles were higher $(P<0 \cdot 05)$ on day 18 compared with day 14. In contrast, the mean IGF-I values in follicles from ACTH-treated gilts increased to a lesser extent by day 18 , and were lower $(P<0 \cdot 05)$ than same day control follicles (Fig. 1).

A representative profile of IGFBP expression in individual FF samples (Fig. 2) demonstrates an upper 'doublet' with an approximate molecular mass of 44 and $40 \mathrm{kDa}$ corresponding to IGFBP-3, and a somewhat smaller band (34 kDa) corresponding to IGFBP-2 (Mondschein et al. 1991, Howard \& Ford 1992). The level of IGFBP 


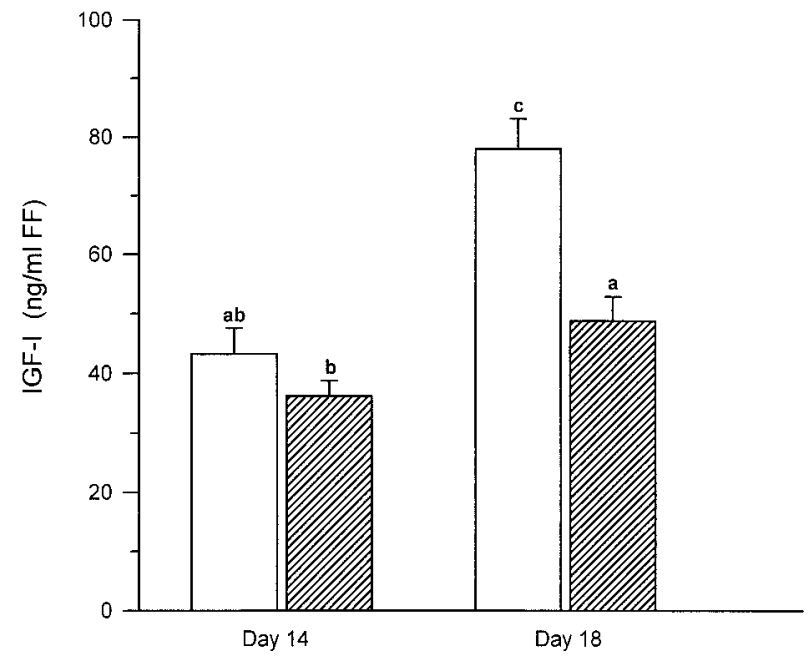

Figure 1 Mean IGF-I concentration ( $\mathrm{ng} / \mathrm{ml} \pm$ S.E.) in the follicular fluid of individual follicles ( $n=70$ for each group) recovered from control (open bars) and ACTH-treated (hatched bars) gilts on day 14 and day 18 of the oestrous cycle. Different superscripts denote statistical differences at a $P<0 \cdot 05$ level of significance.

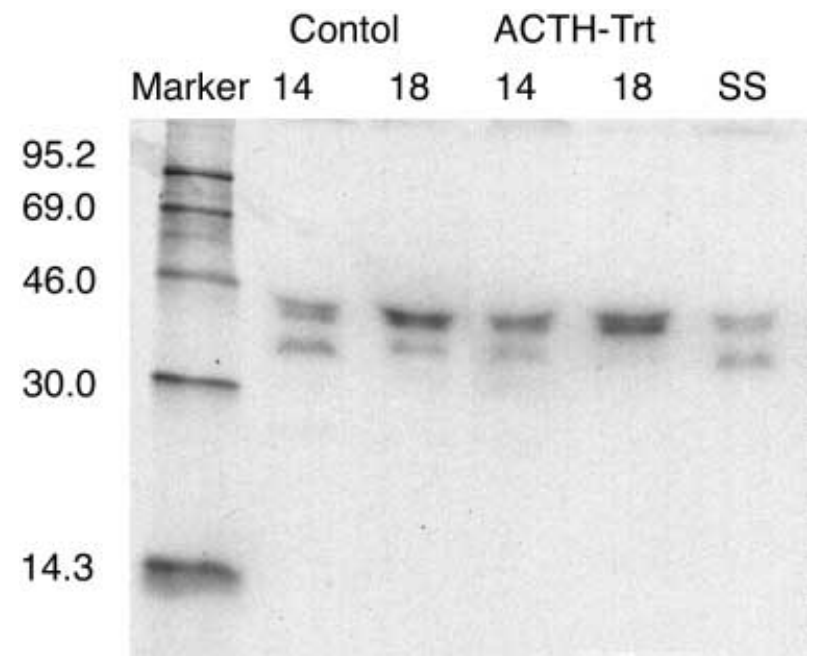

Figure 2 Western ligand blot demonstrating the IGFBP profile in the follicular fluid of individual follicles recovered from control and ACTH-treated (ACTH-Trt) gilts on day 14 and day 18 of the oestrous cycle. SS, serum standard.

expression was calculated as a percentage of the porcine serum standard. In the ACTH-treated group, both IGFBP-2 $(P=0.055)$ and IGFBP-3 $(P=0.066)$ expression tended to be lower on day 14 relative to the same day control group, but the difference did not reach significance (Fig. 3).

Follicular fluid steroid hormone levels

Mean cortisol concentrations $(\mathrm{ng} / \mathrm{ml} \pm$ s.E.) were significantly $(P<0 \cdot 05)$ elevated in the FF of ACTH-treated gilts
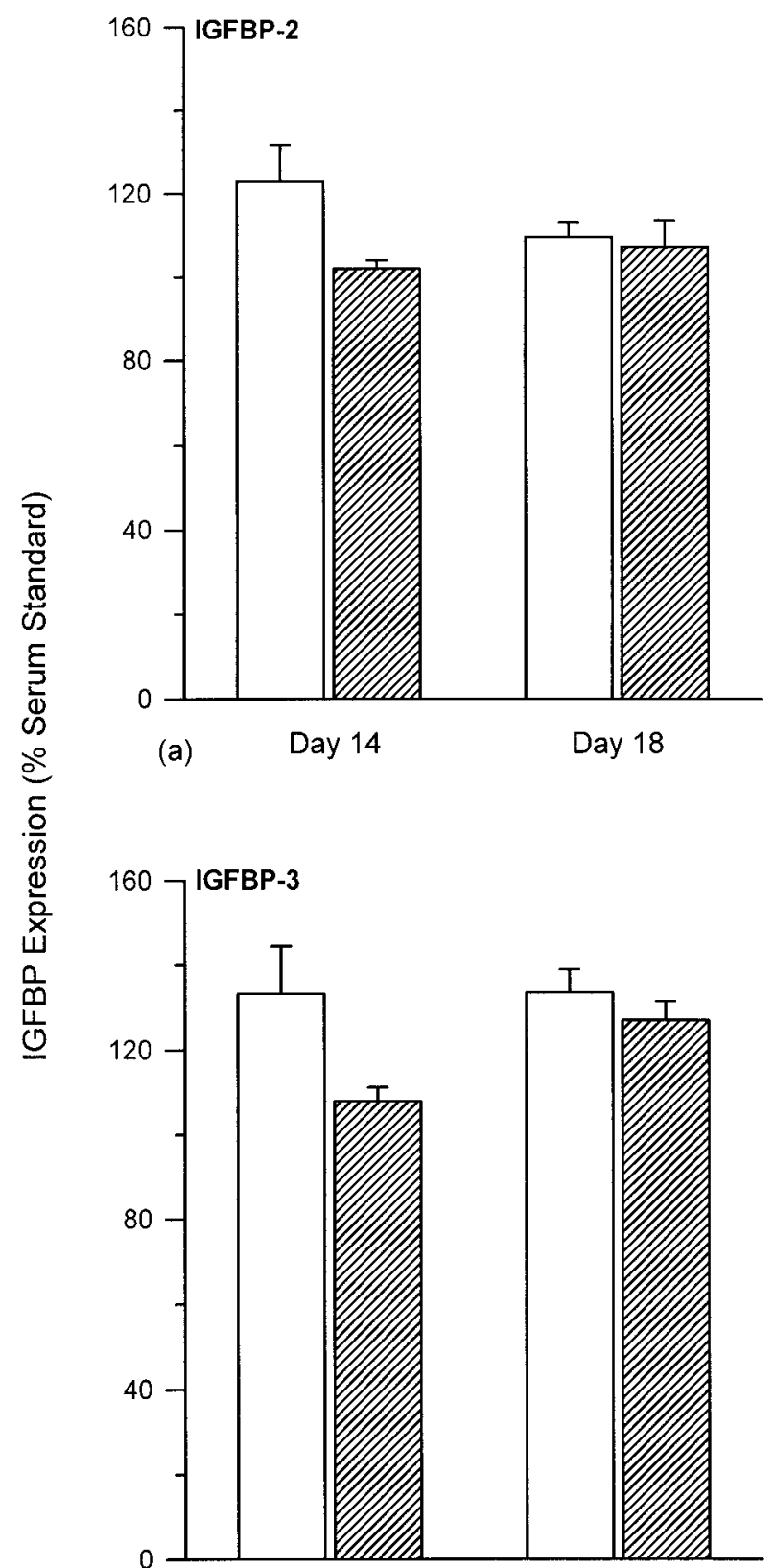

(b)

Day 14

Day 18

Figure 3 Mean levels (\% porcine serum standard \pm S.E.) of (a) IGFBP-2 and (b) IGFBP-3 in the follicular fluid of individual follicles recovered from control (open bars) and $\mathrm{ACTH}$-treated (hatched bars) gilts on day 14 and day 18 of the oestrous cycle.

on day 14 of the cycle; however, by day 18 cortisol values were similar in the control and $\mathrm{ACTH}$-treated follicles (Fig. 4a). Progesterone, $\mathrm{E}_{2}$ and $\mathrm{A}_{4}$ concentrations were each higher $(P<0 \cdot 05)$ on day 18 , relative to day 14 follicles, in both the control and ACTH group 

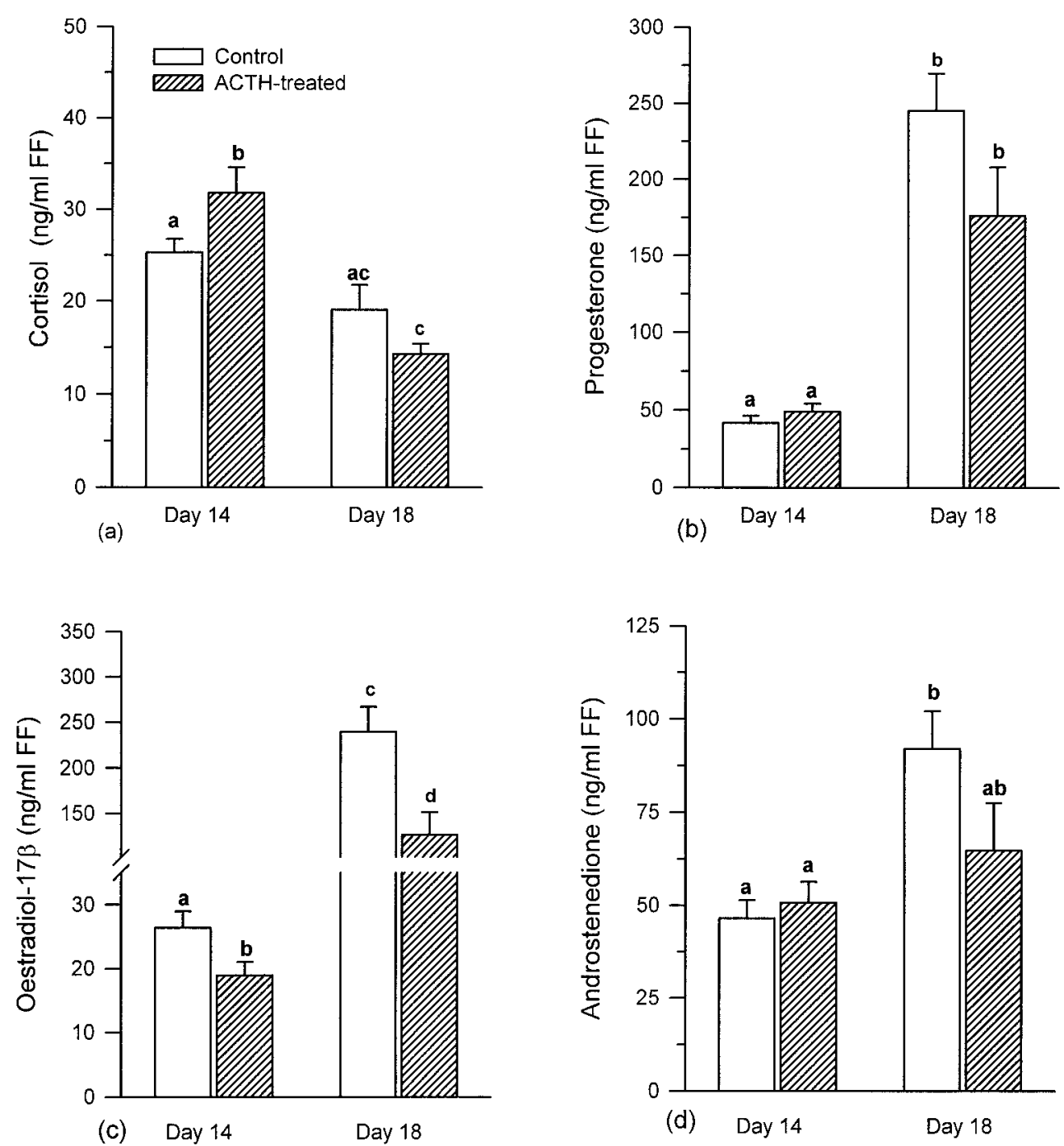

Figure 4 Mean (a) cortisol, (b) progesterone, (c) oestradiol-17 $\beta$ and (d) androstenedione concentrations $(\mathrm{ng} / \mathrm{ml} \pm$ S.E.) in the follicular fluid of individual follicles ( $n=70$ per group) recovered from control (open bars) and ACTH-treated (hatched bars) gilts on days 14 and 18 of the oestrous cycle. Different superscripts denote statistical differences at a $P<0 \cdot 05$ level of significance.

(Fig. 4b,c,d). Follicles from the ACTH gilts were characterized by significantly $(P<0 \cdot 05)$ lower $\mathrm{E}_{2}$ concentrations on both day 14 and day 18 (Fig. 4c), while $\mathrm{P}_{4}$ and $\mathrm{A}_{4}$ values did not differ significantly (Fig. 4b,d).

\section{Granulosa cell IGF-I production}

On day 14, there was no difference between the control and ACTH-treated group in either basal (Fig. 5a) or FSH-stimulated (Fig. 5b) IGF-I production $(\mathrm{ng} / \mathrm{ml})$ by granulosa cells. In contrast, by day 18 both basal (Fig. 5a) and FSH-stimulated (Fig. 5b) IGF-I production by cells from ACTH-treated gilts were significantly $(P<0 \cdot 05)$ lower.

\section{Progesterone and oestradiol-17 $\beta$ production}

Progesterone production $(\mathrm{ng} / \mathrm{ml} \pm$ S.E.) by granulosa cells was dependent on the day of the oestrous cycle as well as on gonadotrophin and IGF-I stimulation. Both FSH and IGF-I treatment stimulated $\mathrm{P}_{4}$ production $(P<0 \cdot 05)$ by day 14 granulosa cells, and no difference was observed between the control and ACTH group in either basal or FSH-mediated $\mathrm{P}_{4}$ levels (Fig. 6a.). However, when the cells were stimulated with IGF-I alone or IGF-I together with $\mathrm{FSH}, \mathrm{P}_{4}$ production by cells from the ACTH-treated gilts was significantly lower $(P<0 \cdot 05)$ (Fig. 6a). Granulosa cells recovered on day 18 also responded to FSH and IGF-I stimulation with increased $\mathrm{P}_{4}$ production (Fig. $6 \mathrm{~b}$ ). 


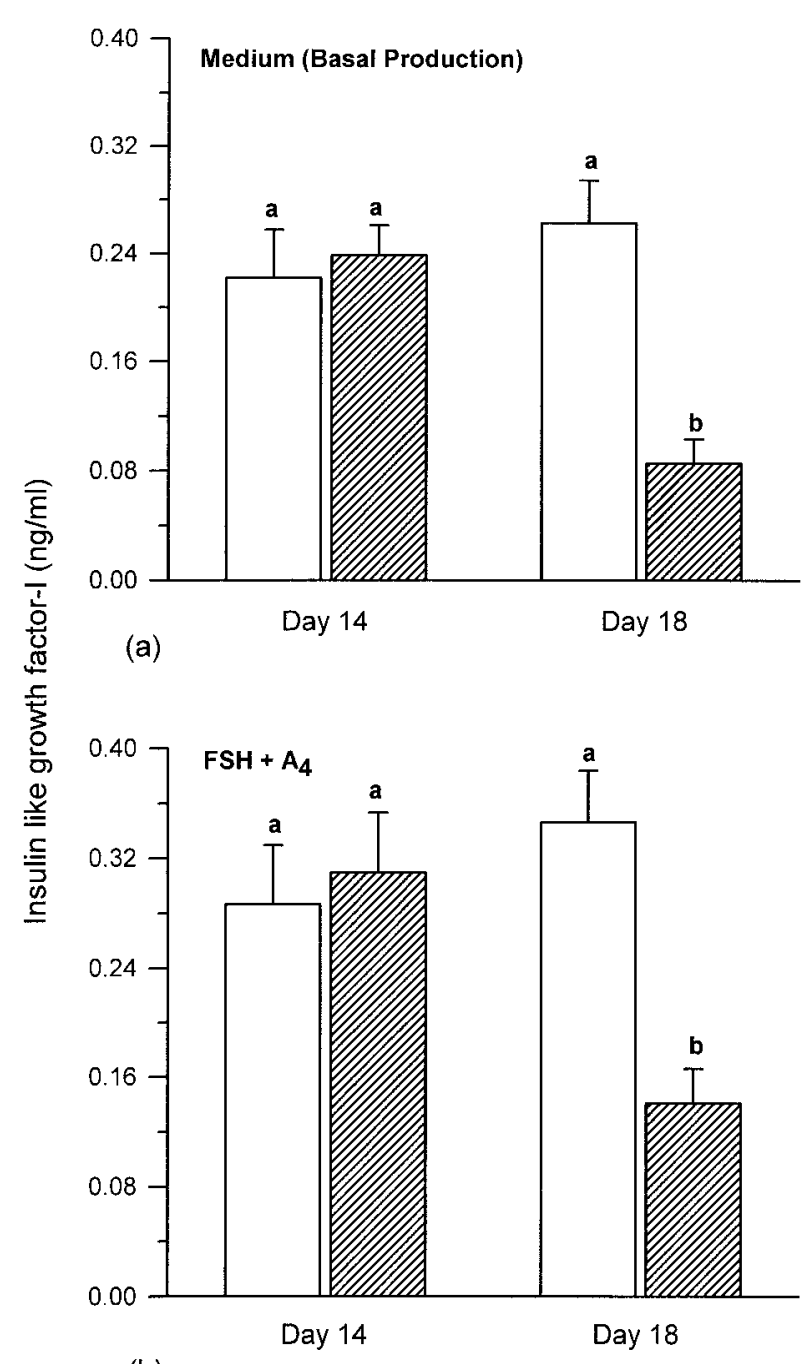

(b)

Figure 5 Mean cumulative IGF-I production $(\mathrm{ng} / \mathrm{ml} \pm$ S.E.) by granulosa cells recovered from control ( $n=5$, open bars) and ACTH-treated ( $n=5$, hatched bars) gilts on day 14 and day 18 of the oestrous cycle. The cells were cultured serum free for 5 days in (a) media alone or (b) with FSH $(10 \mathrm{ng} / \mathrm{ml})$ and androstenedione $\left(\mathrm{A}_{4}, 100 \mathrm{ng} / \mathrm{ml}\right)$. Different superscripts denote statistical differences at a $P<0 \cdot 05$ level of significance.

However, overall basal, FSH-, as well as FSH+IGF-Istimulated $\mathrm{P}_{4}$ production by cells recovered from the ACTH group on day 18 was significantly lower $(P<0 \cdot 05)$ compared with the same day controls (Fig. 6b).

Oestradiol-17 $\beta$ production ( $\mathrm{ng} / \mathrm{ml} \pm$ S.E.) was also influenced by the day of the oestrous cycle as well as by gonadotrophin stimulation (Fig. 7). Stimulation with FSH, either alone or together with IGF-I, increased $(P<0 \cdot 05) \mathrm{E}_{2}$ production by both day 14 and day 18 cells, while stimulation with IGF-I alone did not promote a significant rise in $\mathrm{E}_{2}$. Oestradiol-17 $\beta$ production did not differ

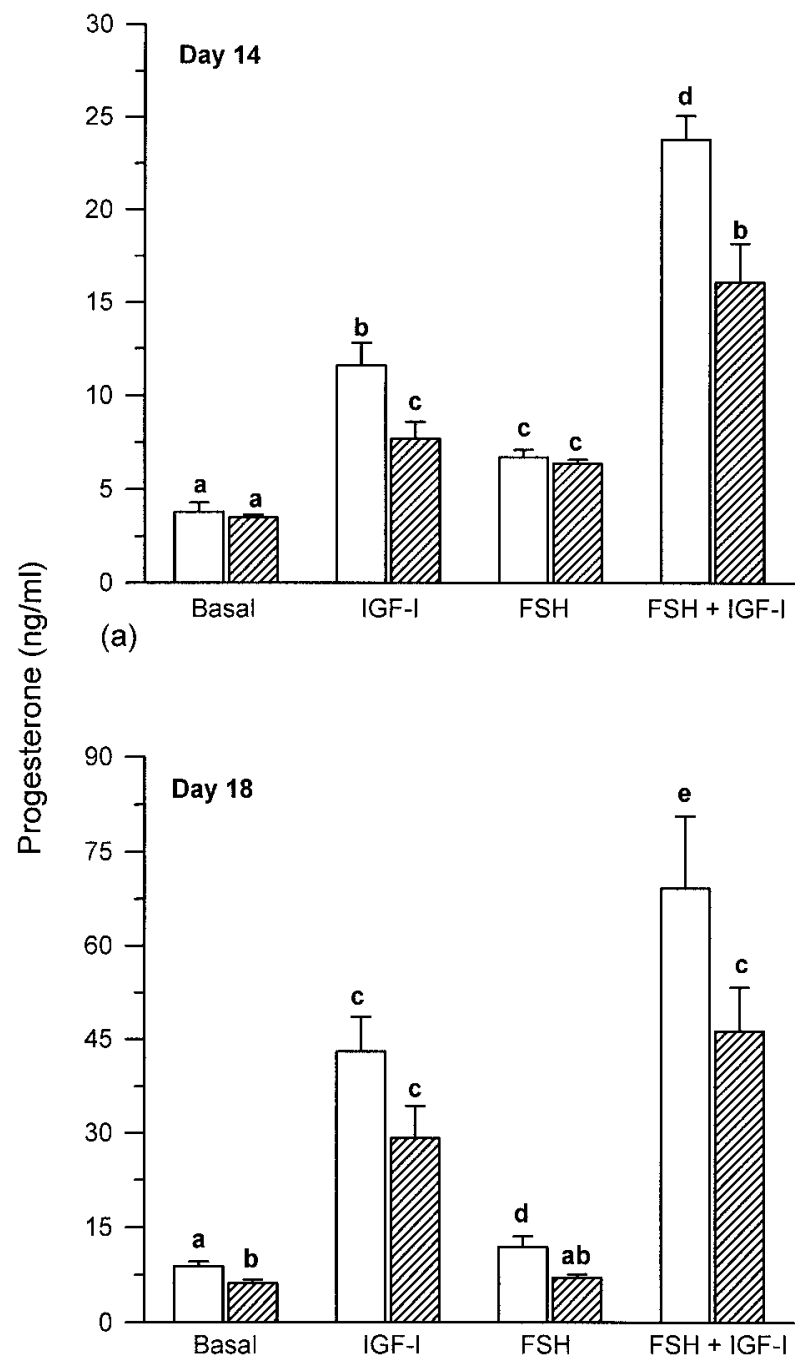

(b)

Figure 6 Mean cumulative progesterone production $(\mathrm{ng} / \mathrm{ml} \pm$ S.E.) by granulosa cells recovered from control ( $n=5$, open bars) and ACTH-treated ( $n=5$, hatched bars) gilts on (a) day 14 , and (b) day 18 of the oestrous cycle. The cells were cultured serum free for 5 days in media alone, IGF-I $(10 \mathrm{ng} / \mathrm{ml}), \mathrm{FSH}(10 \mathrm{ng} / \mathrm{ml})$ and androstenedione $\left(\mathrm{A}_{4}, 100 \mathrm{ng} / \mathrm{ml}\right)$, or IGF-I with FSH and $\mathrm{A}_{4}$. Different superscripts denote statistical differences at a $P<0.05$ level of significance.

between the control and ACTH group on day 14 (Fig. 7a). However, overall basal, FSH- and IGF-I-stimulated $\mathrm{E}_{2}$ production by cells recovered from the ACTH group on day 18 was significantly lower $(P<0 \cdot 05)$ relative to the same day controls (Fig. 7b).

\section{Discussion}

In this study, we demonstrate that ACTH administered during the luteal phase of the oestrous cycle to elevate 


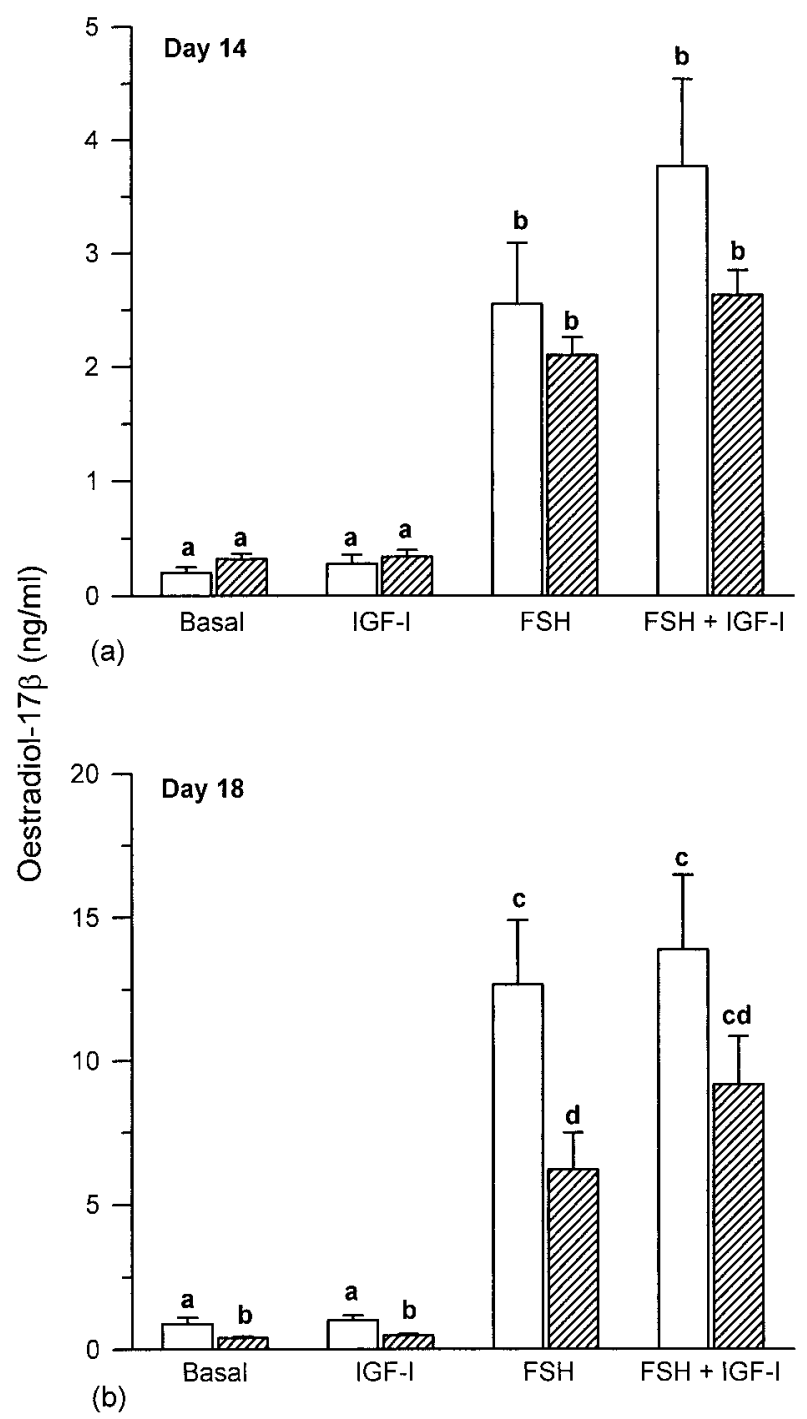

Figure 7 Mean cumulative oestradiol- $17 \beta$ production $(\mathrm{ng} / \mathrm{ml} \pm$ S.E. $)$ by granulosa cells recovered from control $(n=5$, open bars) and ACTH-treated ( $n=5$, hatched bars) gilts on (a) day 14 , and (b) day 18 of the oestrous cycle. The cells were cultured serum free for 5 days in media alone, IGF- $(10 \mathrm{ng} / \mathrm{ml}), \mathrm{FSH}(10 \mathrm{ng} / \mathrm{ml})$ and androstenedione $\left(\mathrm{A}_{4}, 100 \mathrm{ng} / \mathrm{ml}\right)$, or IGF-I with $\mathrm{FSH}$ and $\mathrm{A}_{4}$. Different superscripts denote statistical differences at a $P<0 \cdot 05$ level of significance.

endogenous glucocorticoid levels, can alter ovarian IGF-I and steroid hormone production and potentially impede follicle maturation. Cortisol-mediated disruptions in steroid hormone production by granulosa cells have previously been demonstrated in a number of in vitro studies. Treatment with high glucocorticoid concentrations during culture lowers FSH-stimulated $\mathrm{E}_{2}$ synthesis, but enhances $\mathrm{P}_{4}$ production by murine, porcine and bovine granulosa cells (Schoonmaker \& Erickson 1983, Danisova et al. 1987, Kawate et al. 1993). Lower IGF-I production, and IGF- stimulated steroid hormone synthesis by porcine granulosa cells, were also observed in response to culture with high levels of cortisol (Viveiros \& Liptrap 1999). However, it was not apparent whether marked elevations of glucocorticoid hormones would elicit similar disruptions in vivo. Hence, in the current study an increase in endogenous glucocorticoid levels was induced by ACTH administration. This treatment raises both plasma and FF cortisol concentrations. However, the subsequent decline in cortisol levels was considerably slower in FF after cessation of treatment (Montgomery et al. 1997), indicating that follicular cells may be exposed to high glucocorticoid concentrations for a longer period than that suggested by plasma levels.

Follicles collected from the ovaries of ACTH-treated gilts were characterized by disruptions in IGF-I and steroid hormone levels in FF. Immediately after ACTH treatment was discontinued, lower $\mathrm{E}_{2}$ levels were evident, and by day 18 (5 days after treatment was discontinued) IGF-I concentrations were also significantly attenuated in the FF of ACTH-treated gilts. The reduced IGF-I levels were attributed to a decrease in granulosa cell IGF-I synthesis. Granulosa cells collected 5 days post ACTH-treatment produced significantly less IGF-I when placed in culture, with or without FSH stimulation. Attenuation of local IGF-I synthesis in the ovary may impair subsequent follicle development. Ovarian steroid hormone production (Veldhuis et al. 1986, Urban et al. 1990), gonadotrophin receptor expression, and cell replication are all affected by IGF-I stimulation (Adashi et al. 1985b, Maruo et al. 1988). Higher IGF-I concentrations are also reported in larger porcine follicles and following gonadotrophin treatment (Hammond et al. 1988, Samaras et al. 1994), suggesting that IGF-I levels in FF may be developmentally regulated.

The adverse effects observed with ACTH treatment are thought to be mediated by subsequently elevated glucocorticoid hormone levels. High cortisol concentrations were measured in FF following ACTH treatment. Receptors for cortisol have been identified in rat granulosa cells (Schreiber et al. 1982), and previous studies report glucocorticoid-mediated suppression of IGF-I synthesis in a number of different cell or tissue types in culture. Exposure to cortisol has been shown to reduce IGF-I levels in the culture medium of liver cells (Binoux et al. 1982), and to attenuate IGF-I mRNA expression as well as IGF-I protein secretion by rat osteoblast and fibroblast cultures (McCarthy et al. 1990). Glucocorticoid analogues, such as dexamethasone, also specifically lower IGF-I mRNA expression in neuronal and glial cells within hours of culture with no change in total DNA content (Adamo et al. 1989, McCarthy et al. 1990), thus suggesting an effect of cortisol at the transcriptional level. However, it should be noted that glucocorticoids can influence posttranscriptional events by affecting mRNA stability (Frost et al. 1993). 
Glucocorticoids can also suppress IGFBP synthesis by different cell types in culture. For example, cortisol lowers IGFBP production by rat (Chen et al. 1991) and human osteoblast cells by attenuating specific IGFBP mRNA expression (Okazaki et al. 1994). The IGFBPs are thought to regulate IGF-I availability and delivery to target tissues (Clemmons 1992), and hence disruptions in binding protein levels may influence IGF-I action. Evaluation of the IGFBP profile in control and ACTH-treated gilts confirmed the presence of IGFBP-3 and IGFBP-2 in the FF of individual follicles. Both of these proteins have previously been detected in porcine FF and are known products of granulosa and luteal cells (Howard \& Ford 1992, Grimes et al. 1994). IGFBP-4 and -5 have also been measured in porcine FF, but were not detected in the current study, indicating that their concentrations are too low (in individual follicles) to be discerned with this method. However, significant shifts in IGFBP expression in FF were not observed post ACTH treatment and this result suggests that elevated glucocorticoid hormone levels in the ovary may be less detrimental to binding protein synthesis than to IGF-I.

Treatment with ACTH also disrupted IGF-stimulated steroid hormone synthesis. On day 14, IGF-stimulated $\mathrm{P}_{4}$ production by granulosa cells recovered from the ACTH-treated group was significantly lower. In contrast, both basal and FSH-stimulated $\mathrm{P}_{4}$ synthesis were unaffected, and indicate a specific effect on IGF-I action rather than an overall suppression of cell function. Similar findings were observed previously when granulosa cells were directly exposed to high levels of cortisol in vitro (Viveiros \& Liptrap 1999). By day 18 (5 days post ACTH treatment) both overall $\mathrm{P}_{4}$ and $\mathrm{E}_{2}$ synthesis by granulosa cells were lower in the ACTH group. In addition, lower $\mathrm{E}_{2}$ concentrations were evident in the FF of ACTH-treated gilts on both days 14 and 18. Previous studies have reported lower oestrogen levels in FF recovered from gilts treated with dexamethasone or ACTH during the luteal phase of the cycle (Fraustchy \& Liptap 1988, Liptrap \& Cummings 1991). In this investigation, the decrease in IGF-I and steroid production observed 5 days after ACTH treatment was discontinued suggests that the effects of cortisol, at the earlier stage of the cycle, may have hindered subsequent follicle development or, potentially, promoted follicle atresia. Follicles from the ACTHtreated group were smaller in diameter on day 18; moreover, both IGF-I and steroid hormone levels in FF were significantly lower and suggestive of follicles at an earlier stage of maturation.

The mechanism(s) whereby glucocorticoid hormones influence IGF-I action is not well understood. Granulosa cells are normally responsive to IGF-I, as follicles develop with sustained IGF receptor expression (Maruo et al. 1988, Hylka et al. 1989). In the current study, there was a suppressive effect on IGF-I, but not FSH action, indicating a possible influence on IGF-I receptor expression and/or binding affinity. Results from previous studies that addressed this were variable; in one investigation dexamethasone lowered IGF-I receptor mRNA expression in primary rat granulosa cell culture (Botero et al. 1993), while in another study dexamethasone treatment prevented IGF-I receptor down regulation in porcine granulosa cells (Urban et al. 1994). Further analysis is, therefore, needed to determine the mechanism whereby glucocorticoids influence IGF-I action, and to ascertain what step(s) may be affected in the steroidogenenic pathway. IGF-I can promote ovarian steroidogenesis through a number of different ways, ranging from enhanced cholesterol substrate availability to a direct increase in $\mathrm{P}_{450}$ SCC enzyme activity and mRNA expression (Veldhuis et al. 1986, 1987, Urban et al. 1990).

In summary, the results of this study demonstrate that high levels of glucocorticoids can detrimentally influence the porcine ovarian IGF-I system in vivo. Exposure to elevated glucocorticoid concentrations following ACTH treatment reduced IGF-I synthesis by porcine granulosa cells resulting in lower IGF-I concentrations in FF. Elevated glucocorticoid levels also suppressed IGFstimulated $\mathrm{P}_{4}$ production by granulosa cells, but did not impair gonadotrophin stimulation, indicating a possible effect on IGF-I receptor expression and/or binding affinity. A reduction in ovarian IGF-I synthesis may have important implications for follicle maturation, as IGF-I plays a vital role in regulating ovarian cell proliferation and steroid hormone synthesis (Guidice 1992, Hammond et al. 1993). Follicles recovered 5 days post ACTH treatment appeared to be less mature; the follicles were smaller in size and were characterized by lower IGF-I and steroid hormone concentrations in FF, as well as lower steroid production by granulosa cells.

\section{Acknowledgements}

This project was supported by the Ontario Ministry of Agriculture, Food and Rural Affairs, and a grant from the Natural Sciences and Engineering Council of Canada. The authors are thankful to Dr M Shoukri for his valuable assistance with the statistical analysis.

\section{References}

Adamo M, Werner H, Farnsworth W, Roberts Jr CT, Raizada M \& LeRoith D 1989 Dexamethasone reduces steady state insulin-like growth factor-I messenger ribonucleic acid levels in rat neuronal and glial cells in primary culture. Endocrinology 123 2565-2570.

Adashi EY, Jones PC \& Hsueh AJ 1981 Synergistic effect of glucocorticoids on the stimulation of progesterone production by follicle-stimulating hormone in cultured rat granulosa cells. Endocrinology 109 1888-1894.

Adashi EY, Resnick CE, D’Ercole AJ, Svoboda ME \& Van Wyk JJ $1985 a$ Insulin-like growth factors as intraovarian regulators of granulosa cell growth and function. Endocrine Reviews 6 400-420. 
Adashi EY, Resnick CE, Svoboda ME \& Van Wyk JJ 1985 b Somatomedin-C enhances induction of luteinizing hormone receptors by follicle-stimulating hormone in cultured rat granulosa cells. Endocrinology 116 2369-2375.

Barb CR, Kraeling RR, Rampacek GB, Fonda ES \& Kiser TE 1982 Inhibition of ovulation and $\mathrm{LH}$ secretion in the gilt after treatment with ACTH or hydrocortisone. Journal of Reproduction and Fertility 64 85-92.

Binoux M, Lassarre C \& Hardouin N 1982 Somatomedin production by rat liver in organ culture. III. Studies on the release of insulin-like growth factor and its carrier protein measured by radioligand assays. Effects of growth hormone, insulin and cortisol. Acta Endocrinologica 99 422-430.

Botero LF, Roberts CT, Le Roith D Jr, Adashi EY \& Hernandez ER 1993 Insulin-like growth factor-I gene expression by primary cultures of ovarian cells: insulin and dexamethasone dependence. Endocrinology 132 2703-2708.

Cataldo NA \& Guidice LC 1992 Insulin-like growth factor binding protein profiles in human ovarian follicular fluid correlate with follicular functional status. Journal of Clinical Endocrinology and Metabolism 74 821-829.

Chen TL, Chang LY, Bates RL \& Perlman AJ 1991 Dexamethasone and 1,25-dihydroxyvitamin D3 modulation of insulin-like growth factor binding proteins in rat osteoblast-like cell cultures. Endocrinology 128 73-80.

Clemmons DR 1992 IGF binding proteins: regulation of cellular actions. Growth Regulation 2 80-87.

Danisova A, Sebokova E \& Kolena J 1987 Effect of corticosteroids on estradiol and testosterone secretion by granulosa cells in culture. Experimental and Clinical Endocrinology 89 165-173.

Fonda ES, Rampacek GB \& Kraeling RR 1984 The effect of adrenocorticotropin or hydrocortisone on serum luteinizing hormone concentrations after adrenalectomy and/or ovariectomy in the prepubertal gilt. Endocrinology 114 268-273.

Frautschy SA \& Liptrap RM 1988 Anovulation and plasma hormone concentrations after administration of dexamethasone during the middle of the luteal phase in sows undergoing estrous cycles. American Journal of Veterinary Research 49 1270-1275.

Frost G, Rhee K \& Thompson E 1993 Glucocorticoid regulation of thymidine kinase (TK-1) expression in L929 cells. Journal of Biological Chemistry 268 6745-6754.

Gadsby JE, Lovdal JA, Samaras S, Barber JS \& Hammond JM 1996 Expression of the messenger ribonucleic acids for insulin-like growth factor-I and insulin-like growth factor binding proteins in porcine corpora lutea. Biology of Reproduction 54 339-346.

Gee CM, Geissinger HD \& Liptrap RM 1991 Morphometric and steroid hormone changes associated with experimental anovulatory follicles in the sow. Canadian Journal of Veterinary Research $\mathbf{5 5}$ 206-211.

Grimes RW, Barber JA, Shimasaki S, Ling N \& Hammond JM 1994 Porcine ovarian granulosa cells secrete insulin-like growth factorbinding proteins- 4 and -5 and express their messenger ribonucleic acids: regulation by follicle-stimulating hormone and insulin-like growth factor-I. Biology of Reproduction 50 695-701.

Guidice LC 1992 Insulin-like growth factors and ovarian follicular development. Endocrine Reviews 13 642-669.

Hammond JM, Hsu C-J, Klindt J, Ainsworth L, Downey BR \& Tsang BK 1988 Gonadotropins increase concentrations of immunoreactive insulin-like growth factor-I in porcine follicular fluid in vivo. Biology of Reproduction 38 304-308.

Hammond JM, Samaras SE, Grimes R, Leighton J, Barber J, Canning SF \& Guthrie HD 1993 The role of insulin-like growth factors and epidermal growth factor-related peptides in intraovarian regulation in the pig ovary. Journal of Reproduction and Fertility 48 117-125.

Hossenlopp P, Seurin D, Segovia-Quinson B, Hardouin S \& Binoux M 1986 Analysis of serum insulin-like growth factor binding proteins using Western blotting: use of the method for titration of the binding proteins and competitive binding studies. Annals of Biochemistry 154 138-143.

Houseknecht KL, Boggs DL, Campion DR, Sartin JL, Kiser TE, Rampacek GB \& Amos HE 1988 Effect of dietary energy source and level on serum growth hormone, insulin-like growth factor I, growth and body composition in beef heifers. Journal of Animal Science 66 2916-2923.

Howard HJ \& Ford JJ 1992 Relationships among concentrations of steroids, inhibin, insulin-like growth factor-I (IGF-I), and IGFbinding proteins during follicular development in weaned sows. Biology of Reproduction 47 193-201.

Hsueh AD \& Erickson GF 1978 Glucocorticoid inhibition of FSHinduced estrogen production in cultured rat granulosa cells. Steroids 32 639-648.

Hylka VW, Caubo B \& Tonetta SA 1989 Analysis of binding sites for IGF-I on membranes from granulosa cells of small, medium and large porcine follicles. In Growth Factors in the Ovary, pp 163-168. Ed AN Hirshfield. New York: Plenum Press.

Kawate N, Inaba T \& Mori J 1993 Effects of cortisol on the amounts of estradiol-17 $\beta$ and progesterone secreted and the number of luteinizing hormone receptors in cultured bovine granulosa cells. Animal Reproduction Science 32 15-25.

Li PS \& Wagner WC 1983 in vivo and in vitro studies on the effect of adrenocorticotropic hormone or cortisol on the pituitary response to gonadotropin releasing hormone. Biology of Reproduction 29 25-37.

Liptrap RM 1970 Effect of corticotrophin and corticosteroids on oestrus, ovulation and oestrogen excretion in the sow. Journal of Endocrinology 47 197-205.

Liptrap RM 1993 Stress and reproduction in domestic animals. Annals of the New York Academy of Sciences 697 275-284.

Liptrap RM \& Cummings E 1991 Steroid concentrations in follicular fluid and ovarian vein plasma in sows treated with dexamethasone. Animal Reproduction Science 26 303-310.

McCarthy TL, Centrelia M \& Canalis E 1990 Cortisol inhibits the synthesis of insulin-like growth factor-I in skeletal cells. Endocrinology 126 1569-1575.

Mahajan DK, Billier RB \& Little AB 1980 Isolation of cortisol binding globulin (CBG) from porcine follicular fluid by affinity chromatography. Journal of Steroid Biochemistry 13 67-71.

Maruo T, Hayashi M, Matsuo H, Ueda Y, Morikawa M \& Mochizuki M 1988 Comparison of the facilitative roles of insulin and insulin-like growth factor-I in the functional differentiation of granulosa cells: in vitro studies with the porcine model. Acta Endocrinologica 117 230-240.

Michael AE \& Cooke BA 1994 A working hypothesis for the regulation of steroidogenesis and germ cell development in the gonads by glucocorticoids and $11 \beta$-hydroxysteroid dehydrogenase (11ßHSD). Molecular and Cellular Endocrinology 100 55-63.

Moberg GP 1987 Influence of the adrenal axis upon the gonads. Oxford Reviews of Reproductive Biology 9 456-496.

Mondschein JS, Etherton TD \& Hammond JM 1991 Characterization of insulin-like growth factor-binding proteins of porcine ovarian follicular fluid. Biology of Reproduction 44 315-320.

Montgomery A, Viveiros M, Cummings E \& Liptrap RM 1997 Rate of decline in cortisol concentrations in ovarian follicles following ACTH treatment in the sow. Canadian Journal of Veterinary Research 61 309-311.

Okazaki R, Riggs BL \& Conover CA 1994 Glucocorticoid regulation of insulin-like growth factor binding protein expression in normal human osteoblast-like cells. Endocrinology 134 126-132.

Samaras SE, Guthrie HD, Barber JA \& Hammond JM 1993 Expression of the mRNAs for insulin-like growth factors and their binding proteins during development of porcine ovarian follicles. Endocrinology 133 2395-2398. 
Samaras SE, Hagen DR, Bryan KA, Mondschein JS, Canning SF \& Hammond JM 1994 Effects of growth hormone and gonadotropin on the insulin-like growth factor system in the porcine ovary. Biology of Reproduction $\mathbf{5 0}$ 178-186.

Schoonmaker JN \& Erickson GF 1983 Glucocorticoid modulation of follicle-stimulating hormone-mediated granulosa cell differentiation. Endocrinology 113 1356-1363.

Schreiber JR, Nakamura K \& Erickson GF 1982 Rat ovary glucocorticoid receptor: identification and characterization. Steroids 39 569-584.

Spicer LJ \& Echternkamp SE 1995 The ovarian insulin and insulin-like growth factor system with an emphasis on domestic animals. Domestic Animal Endocrinology 12 223-245.

Statistical Analysis Systems Institute Inc. 1985 SAS User's Guide: Statistics. Gary, NC: SAS Institute Inc.

Tetsuka M, Thomas FJ, Thomas MJ, Anderson RA, Mason JI \& Hillier SG 1997 Differential expression of messenger ribonucleic acids encoding 11 $\beta$-hydroxysteroid dehydrogenase types 1 and 2 in human granulosa cells. Journal of Clinical Endocrinology and Metabolism 82 2006-2009.

Urban RJ, Garmey JC, Shupnik MA \& Veldhuis JD 1990 Insulin-like growth factor type I increases concentrations of messenger ribonucleic acid encoding cytochrome P450 cholesterol side-chain cleavage enzyme in primary cultures of porcine granulosa cells. Endocrinology 127 2481-2488.
Urban RJ, Bodenburg YH, Nagamani M \& Pierce J 1994 Dexamethasone potentiates insulin-like growth factor-I actions in porcine granulosa cells. American Journal of Physiology 267 E115-E123.

Veldhuis JD, Rogers RJ, Dee A \& Simpson ER 1986 The insulin-like growth factor, somatomedin $\mathrm{C}$, induces synthesis of cholesterol side chain cleavage cytochrome P-450 and adrenodoxin in ovarian cells. Journal of Biological Chemistry 161 2499-2502.

Veldhuis JD, Nestler JE, Strauss JF, Garmy J \& Juchter D 1987 The insulin-like growth factor, somatomedin C, modulates low density lipoprotein metabolism by swine granulosa cells. Endocrinology 121 340-346.

Viveiros MM \& Liptrap RM 1999 Glucocorticoid influence on porcine granulosa cell IGF-I and steroid hormone production in vitro. Theriogenology 51 1027-1043.

Yuan W, Lucy MC \& Smith MF 1996 Messenger ribonucleic acid for insulin-like growth factor-I and -II, insulin-like growth factor binding protein-2, gonadotrophin receptors, and steroidogenic enzymes in porcine follicles. Biology of Reproduction $\mathbf{5 5}$ $1045-1054$.

Received 26 November 1998

Revised manuscript received 27 September 1999

Accepted 2 November 1999 